\title{
Analisis Kinerja Saham LQ-45 Pada PILKADA DKI Jakarta Putaran II 2017
}

\author{
Moh. Zaki Kurniawan \\ Fakultas Ekonomi dan Bisnis Universitas Trunojoyo Madura \\ email: zaki.kurniawan@trunojoyo.ac.id
}

Kata kunci:

PILKADA DKI Jakarta

Indeks LQ 45

Studi Peristiwa

Keywords:

PILKADA DKI Jakarta

Indeks LQ 45

Event Study

Moh. Zaki Kurniawan (2019).

Analisis Kinerja Saham LQ-45 Pada

PILKADA DKI Jakarta Putaran II

2017. Akuntabilitas: Jurnal Ilmiah

Ilmu-Ilmu Ekonomi, 12(2), 87-96

\begin{abstract}
ABSTRAK
Tujuan penelitian ini untuk melihat adanya perbedaan kinerja saham LQ-45 sebelum dan sesudah peristiwa PILKADA DKI Jakarta pada putaran II tahun 2017melalui return, abnormal return, dan cumulative abnormal return di Bursa Efek Indonesia. Penelitian yang berjemis event study ini menggunkan purposive sampling dalam penentuan kelompok saham LQ-45. Periode penelitian selama 20 hari meliputi 10 hari sebelum dan 10 hari setelah peristiwa. Hasil uji paired sample t-test menunjukkan hasil return saham tidak berbeda periode sebelum dan sesudah. Hasil uji paired sample t-test abnormal return dan cumulative abnormal return sebelum dan sesudah peristiwa PILKADA ditemukan tidak terdapat perbedaan.
\end{abstract}

\section{ABSTRACT}

The purpose of this study is to see the differences in the performance of LQ-45 shares before and after the Jakarta Election in the second round of 2017 through returns, abnormal returns, and cumulative abnormal returns on the Indonesia Stock Exchange.This study uses purposive sampling in the LQ 45 index. This type of research is an event study. The research period for 20 days: 10 days before and 10 days after event. Hypothesis testing uses paired sample t-test. Paired sample t-test test results showed the stock return did not differ before and after the period. The results of paired sample $t$ test abnormal return and cumulative abnormal return before and after the election were found to be no difference.

\section{PENDAHULUAN}

DKI Jakarta sebagai Ibukota Negara Kesatuan Republik Indonesia memiliki peran penting sebagi epicentrum perekonomian. Peristiwa politik yang terjadi di 
DKI Jakarta akan menjadi perhatian utama bagi para investor pasar modal Indonesia. Peristiwa politik dapat mempengaruhi harga saham di Bursa Efek Indonesia jika suatu peristiwa politik tersebut berkonteks nasional. Adanyan gejolak politik selama PILKADA DKI tahun 2017 dalam proses penentuan pemenangnya telah menimbulkan faktor ketidakpastian. Terjadinya beberapa gelombang pro dan kontara aksi massa masing-masing pendukung calon Gubernur DKI Jakarata pada awal November dan pertengahan Desember 2016 tentunya membuat investor harus waspada pada perkembangan situasi politik peristiwa PILKADA DKI tersebut.

Informasi yang terkandung dalam sebuah peristiwa akan memberikan sinyal kepada investor guna membantu dalam proses pengambilan keputusan investasi (Hartono, 2014:410). Keputusan investasi oleh investor dari sebuah sinyal tersebut akan diinterpretasikan terlebih dahulu dan dianalisis kandungan informasi tersebut sebagai sinyal good news atau sinyal bad news. Jika sebuah informasi dianggap sebagai sinyal good news, maka investor akan memiliki ketertarikan untuk melaksanakan aktifitas kegiatan perdagangan saham sehingga akan menimbulkan reaksi pasar yang dicerminkan dari adanya perubahan terjadi dalam harga dan volume saham yang perdagangankan. Beberapa penelitian terdahulu telah meneliti adanya hubungan sebuah peristiwa dengan reaksi pasar modal melalui aktifitas perdagangan saham (Hasanah dan Oktaviani, 2017; Ayuni, 2016; Apriliastuti, 2015; Ayu dan Istianingsih, 2015).

Untuk menilai sebuah peristiwa apakah memiliki information content, salah satunya menggunakan teknik event study. Efisiensi pasar bentuk setengah kuat yang sering terjadi diBursa efek Indonesia pengujiannya dapat menggunakan event study yang berguna untuk mempelajari adanya reaksi pasar terhadap suatu event yang informasinya terpublikasikan dalam suatu pengumuman (Hartono, 2015: 623). Penelitian ini dalam menguji adanya information content dari suatu pengumuman tersebut menggunakan ukuran return, abnormal return dan cumulative abnormal return saham.

Penelitian ini menggunakan purposive samping dalam menentukan kelompoksaham indeks LQ-45 berdasarkan pertimbangan bahwa penelitian 
menggunakan data harga harian yang memiliki likuiditas tinggi sehingga harus menggunakan perusahaan yang aktif diperdagangkan dan direspon oleh pasar.

\section{METODE PENELITIAN}

Jenis penelitian ini adalah event study. Metode analisis data yang digunakan adalah uji beda statistik parametrik dengan menggunakan paired sampel T-test dari data dokumentasi.

\section{Hipotesis}

H1 = Terdapat perbedaan terhadap return saham LQ-45 sebelum dan sesudah Pilkada DKI Jakarta 2017 putaran II.

$\mathbf{H 2}$ = Terdapat perbedaan terhadap abnormal return saham LQ-45 sebelum dan sesudah Pilkada DKI Jakarta 2017 putaran II.

H3 = Terdapat perbedaan terhadap cumulative abnormal return saham LQ-45 sebelum dan sesudah Pilkada DKI Jakarta 2017 putaran II.

\section{Pengumpulan Data}

Data dokumentasidikumpulkan secara langsung dari website resmi Bursa Efek Indonesia $\underline{w w w . i d x . c o . i d}$ dari kelompok perusahaan saham LQ-45. Periode penelitian terdiri dari estimate period dan window period. Estimate period mulai tanggal 18 Juli 2016 hingga 3 April 2017. Window period dilakukan selama 20 hari bursa mulai tanggal 4 April 2017 sampai dengan 5 Mei 2017. Window period terdiri dari 10 hari pre event dan 10 hari post event.

\section{Variabel Operasional}

1. PILKADA DKI Jakarta 2017.

Event politik pemilihan kepala daerah yang terjadi pada tanggal 19 April 2017.

2. Harga saham.

Harga saham yang digunakan adalah clossing price (harga penutupan) selama periode pengamatan.

3. Return saham.

Return saham merupkan hasil yang diperoleh dari investasi saham yang dilakukan selama periode pengamatan.

4. Abnormal Return.

Return yang sesungguhnya terjadi melebihi return normal. 
5. Cumulative Abnormal Return.

Abnormal Return yang dijumlahkan selama periode tertentu.

\section{Analisis Data}

Analisisa data yang dipergunakan normalitasnya menggunakan uji one sample Kolmogrov-Smirnov test dan analisinya menggunakan statistik parametic dengan tingkat signifikasi 0,05ini meliputi analisis variabel return, abnormal return, dan cumulative abnormal return.

\section{PEMBAHASAN}

Gambar 1 menunjukkan return saham LQ-45 sebelum dan sesudah PILKADA DKI Jakarta putaran II sebesar -0,001537 dan -0,000097 sehingga dapat ditarik kesimpulan ditemukan rata-rata return saham sebelum lebih besar nilainya daripada rata-rata return saham sesudahnya.

\section{Gambar 1}

Grafik Return Saham

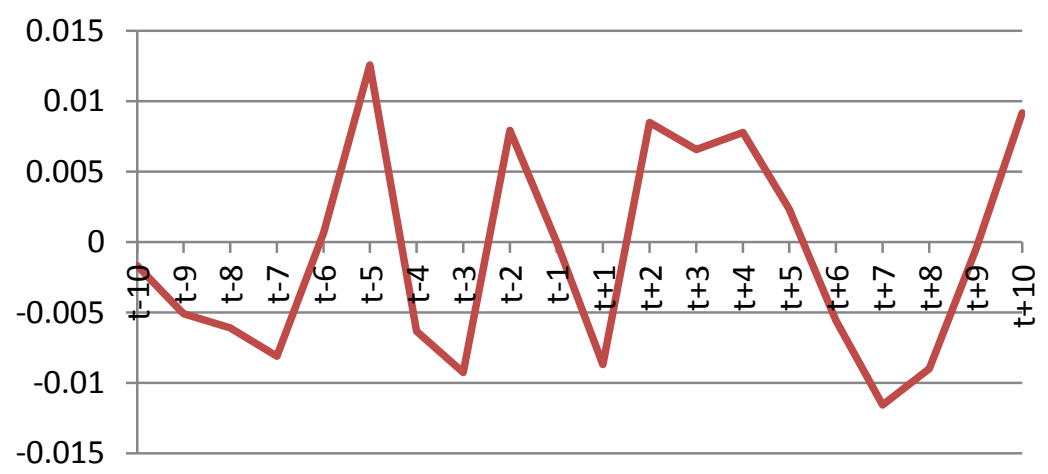

Sumber: Data Diolah, 2019

Tabel 2

Hasil Uji Statistik Return Saham LQ45 Sebelum dan Sesudah

\begin{tabular}{|c|c|}
\hline d.f & 44 \\
\hline$t_{\text {hitung }}$ & $-0,405$ \\
\hline$t_{\text {tabel }}\left(\frac{a}{2}, n-1\right)$ & 2,0154 \\
\hline Asymp.Sig. $(2-$ tailed $)$ & 0,695 \\
\hline Keterangan & Tidak Signifikan \\
\hline
\end{tabular}

Sumber: Data Diolah, 2019 
Tabel 2 diatas menunjukkan bahwa t hitung -0,405 berada di dalam daerah penerimaan $H_{0}\left(\frac{-a}{2}, n-1\right)<\mathrm{t}<\left(\frac{a}{2}, n-1\right)$ karena $-2,0154<-0,405<2,0154$. Maka dapat diambil keputusan untuk menerima $H_{0}$ dan menolak $H_{1}$. Jika ditinjau dari nilai probabilitasnya Asymp. Sig. (2-tailed) dimana nilai probablitasnya 0,695 > 0,05 maka diperoleh keputusan untuk menerima $H_{0}$ dan menolak $H_{1}$. Berdasarkan pada dua hal tersebut maka diperoleh hasil kesimpulan tidak terdapat perbedaan return saham LQ-45 sebelum dan sesudah peristiwa.

Hal ini diduga bahwa peristiwa tersebut tidak memiliki information content. sehingga investor tidak bereaksi terhadap peristiwa PILKADA DKI Jakarta 2017 putaran II tanggal 19 April 2017 sehingga tidak berpengaruh terhadap fluktuasi harga saham. Pada periode tersebut investor lebih berhati-hati dalam melakukan pembelian saham karena masih adanya keraguan dikalangan para investor terhadap hasil dari peristiwa tersebut. Hal ini juga dapat dijadikan sebagai indikasi bahwa masih terdapatnya keraguan dikalangan investor terhadap pelaksanaan PILKADA DKI Jakarta 2017 putaran II. Bila ditinjau dari variabel return maka temuan dalam penelitian ini mendukung penelitian terdahulu oleh Thrisye dan Simu (2013), dan Sandrayati (2013).

\section{Abnormal Return}

Berdasarkan gambar 2 menunjukkan bahwa abnormal return saham sebelum dan sesudah PILKADA DKI Jakarta 2017 putaran II sebesar 0,009585 dan 0,010240. Terjadi kecenderungan peningkatan yang relatif kecil dibandingkan sebelum dan sesudah peristiwa, walaupun nampak kecenderungan peningkatan nilai tersebut mampu membawa ke nilai abnormal return yang tetap positif. Hal ini mengindikasikan bahwa investor masih lebih berhati-hati dalam melakukan pembelian saham dan investor mempunyai preferensi yang berbeda-beda terhadap peristiwa tersebut. Walaupun sebelumnya nampak ada rata-rata abnormal return yang bernilai negatif dihasilkan pada hari sekitar periode pengamatan, yaitu $\mathrm{H}+7$ yang menandakan respon negatif dari pelaku pasar. Diperoleh strandar deviasi yang menunjukkan kecilnya penyimpangan nilai data sebelum dan sesudah peristiwa sebesar 0,0076471 dan 0,0070971. Deviasi nilai abnormal return pada masa sebelum peristiwa terlihat lebih besar terhadap nilai rata-rata abnormalreturnnya, dibanding 
tersebut menunjukkan juga terdapat variasi yang lebih kecil pada nilai data abnormal return sebelum peristiwa dibandingkan dengan nilai abnormal return sesudahnya.

Gambar 2

Grafik Abnormal Return Saham

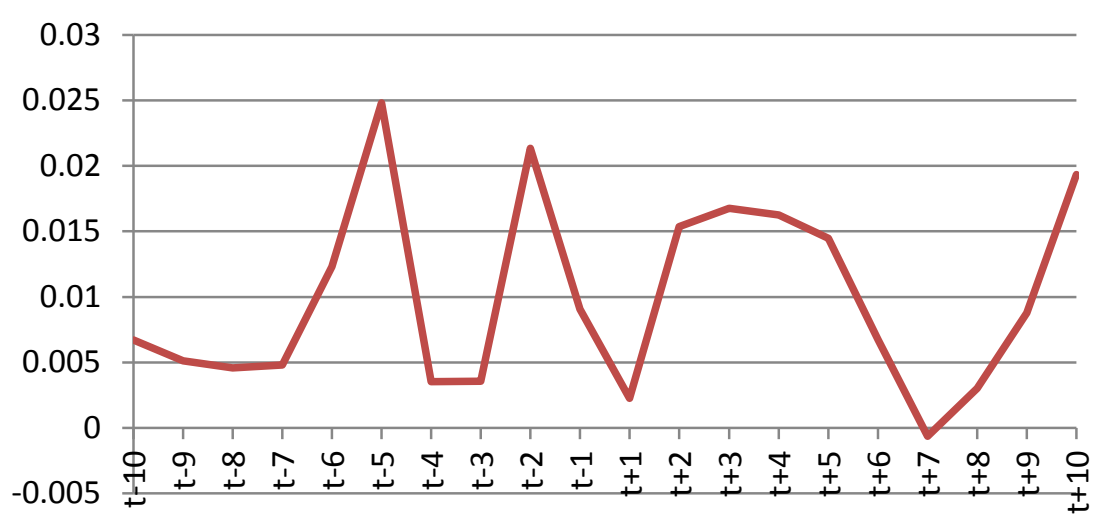

Sumber: Data Diolah, 2019

Tabel 2

Hasil Uji Statistik Abnormal Return Saham LQ45 Sebelum dan Sesudah

\begin{tabular}{|l|l|}
\hline d.f & 44 \\
\hline \multicolumn{1}{|c|}{$t_{\text {hitung }}$} & $-0,195$ \\
\hline \multicolumn{1}{|c|}{$t_{\text {tabel }\left(\frac{a}{2}, n-1\right)}$} & 2,0154 \\
\hline Asymp.Sig. (2- tailed) & 0,849 \\
\hline Keterangan & Tidak Signifikan \\
\hline
\end{tabular}

Sumber: Data Diolah, 2019

Tabel 2 diatas menunjukkan arti bahwa -0,195 berada didalam daerah penerimaan $H_{0}\left(\frac{-\alpha}{2}, n-1\right)<\mathrm{t}<\left(\frac{\alpha}{2}, n-1\right)$ karena $-2,0154<-0,195<2,0154$. Maka dapat diambil keputusan untuk menerima $H_{0}$ dan menolak $H_{2}$. Jika ditinjau dari nilai probabilitasnya Asymp. Sig. (2-tailed) dimana nilai probabilitasnya 0,849 >0,05 maka diperoleh keputusan untuk menerima $H_{0}$ dan menolak $H_{2}$. Dari dua hal diatas maka dapat tarik kesimpulan bahwa tidak ada perbedaaan abnormal return saham LQ-45 sebelum dan sesudah peristiwa PILKADA DKI Jakarta 2017 Putaran II. Mendukung hasil dari penelitian ini yaitu penelitian dari Rusnanda (2013) dan Hasanah dan Oktaviani (2017), tetapi berbeda hasil dari penelitian Cheng dan Christiawan (2011).

\section{Cumulative Abnormal Return}


Gambar 3

Grafik Cumulative Abnormal Return Saham

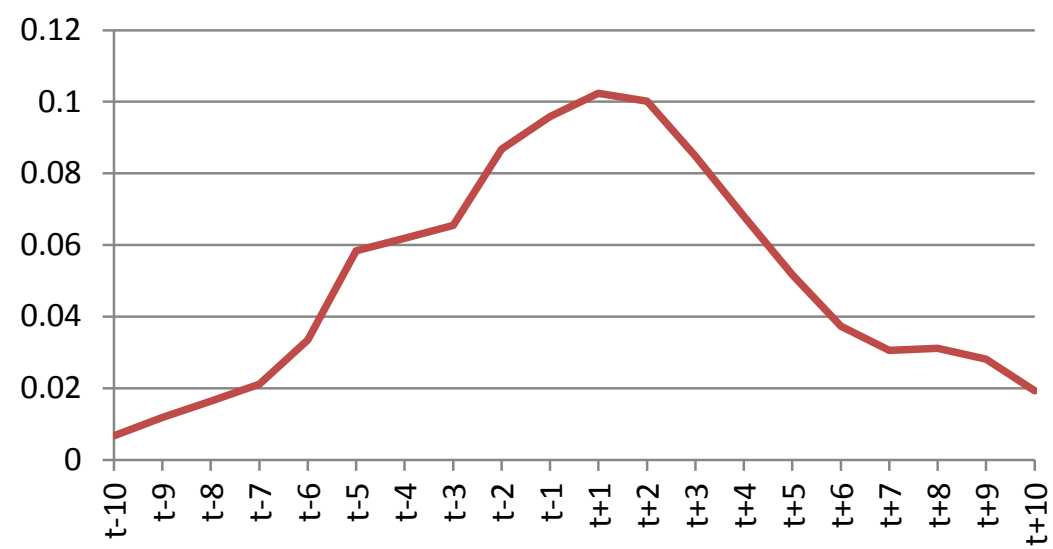

Sumber: Data Diolah, 2019

Berdasarkan gambar 3 terlihat cumulative abnormal return sebelum dan sesudah peristiwa sebesar 0,045799 dan 0,055356. Hasil ini menunjukkan bahwa terjadi kecenderungan peningkatan yang relatif kecil, dimana kecenderungan peningkatan nilai cumulative abnormal return tersebut terjadi pada periode sebelum peristiwa. Nilai deviasi cumulative abnormal return sebelum dan sesudah sebesar 0,0321303 dan 0,0313137 yang berarti bahwa nilai perbandingannya selisih sangat tipis dibandingkan dengan nilai deviasi pada rata-rata variabel return dan abnormal return. Sesuai gambar 3 tersebut nampak bahwa terjadi peningkatan dan penurunan akumulasi return saham pada periode setelah tanggal peristiwa $\mathrm{H}-10$ sampai dengan $\mathrm{H}+1$.

Tabel 3

Hasil Uji Statistik Cumulative Abnormal Return Saham LQ45

Sebelum dan Sesudah

\begin{tabular}{|c|c|}
\hline d.f & 44 \\
\hline$t_{\text {hitung }}$ & $-0,484$ \\
\hline$t_{\text {tabel }\left(\frac{a}{2}, n-1\right)}$ & 2,0154 \\
\hline Asymp.Sig. (2- tailed) & 0,640 \\
\hline Keterangan & Tidak Signifikan \\
\hline
\end{tabular}

Sumber: Data Diolah, 2019 
Tabel 3 diatas menunjukkan arti bahwa $-0,484$ berada didalam daerah penerimaan $H_{0}\left(\frac{-\alpha}{2}, n-1\right)<\mathrm{t}<\left(\frac{\alpha}{2}, n-1\right)$ karena $-2,0154<-0,484<2,0154$. Maka dapat diambil keputusan untuk menerima $H_{0}$ dan menolak $H_{3}$. Jika ditinjau dari nilai probabilitasnya Asymp. Sig. (2-tailed) dimana nilai probabilitasnya 0,640 > 0,05 maka diperoleh keputusan untuk menerima $H_{0}$ dan menolak $H_{3}$. Berdasarkan hasil dari dua hal tersebut maka dapat diambil kesimpulan bahwa tidak ditemukan perbedaan cumulative abnormal return saham LQ-45 sebelum dan sesudah peristiwa. Hal ini dikarenakan para investor menilai bahwa peristiwa tersebut tidak berdampak pada perekonomian perusahaan, sehingga para investor melakukan jual beli saham seperti aktifitas perdagangan pada hari biasa. Hasil penelitian ini sesuai hasil penelitian terdahulu dari Ayu dan Istianingsih (2015) tetapi bertolak belakang dengan penelitian Pahala, Jaya, dan Meilisa (2012).

\section{KESIMPULAN}

1. Tidak terdapat perbedaan antara return saham sebelum dan sesudah peristiwa. Artinya peritiwa politik pada 19 April 2017 tersebut tidak mempengaruhi fluktuasi harga saham terhadap perusahaan maupun para investor.

2. Pada abnormal return saham tidak terdapat pengaruh yang ditimbulkan terhadap sebelum maupun sesudah peristiwa. Hal ini menunjukkan bahwa para investor tidak terpengaruh dengan fluktuasi harga saham karena keuntungan yang didapatkan pun juga relatif tetap.

3. Tidak terdapat perbedaan cumulative abnormal return saham sebelum dan sesudah peristiwa. Hal tersebut menunjukkan bahwa normal atau tidaknya harga saham, perusahaan ataupun investor tidak terpengaruh.

\section{Saran}

1. Bagi Investor

Investor dalam melakukan aktivitas perdagangan saham agar lebih selektif dan cermat dalam menilai suatu peristiwa (event) yang memiliki kandungan informasi atau tidak. Perlu diperhatikan juga apakah nilai ekonomis yang diterima dalam mengambil keputusan bertindak benar dan tepat.

2. Bagi Peneliti Terdahulu 
Penelitian dapat dikembangkan atau ditambahkan variabel tentang aktivitas perdagangan saham, sehingga tidak hanya diketahui pengaruh sebelum dan sesudah peristiwa tetapi juga keadaan pasar saham pada saat peristiwa. Peneliti selanjutnya juga harus memikirkan benar peristiwa yang akan diteliti termasuk periode yang diambil apakah berpengaruh besar terhadap peristiwa atau tidak.

\section{Daftar Pustaka}

Ayu, R. C., \& Istianingsih. (2015). Pengaruh Pengungkapan Corporate Social Responsibility dan Kinerja Keuangan Perusahaan terhadap Cumulative Abnormal Return (Studi Empiris pada Perusahaan Manufaktur yang Terdaftar di BEI tahun 2010-2011). Fakultas Ekonomi dan Bisnis Universitas Mercubuana Jakarta.

Ayuni, A. D. N. (2016). Pengaruh Kinerja Keuangan dan Kebijakan Dividen terhadap Reaksi Investor pada Perusahaan Otomotif. Skripsi Fakultas Ekonomi Sekolah Tinggi Ilmu Ekonomi Indonesia (STESIA) Surabaya.

Fama, E. F. (1991). Efficient Capital Market: II. The Journal of Finance. Vol.46, No.5, pp.1575-1613.

Fama, E.F. (1970). Efficient Capital Market: A Review of Theory and Empirical Work, Journal of Financial. Vol.25, pp.383-417.

Hasanah, A. N., \& Oktaviani, T. M. (2017). Analisis Kinerja Perusahaan dan Abnormal Return Saham Sebelum dan Sesudah Akuisisi. Skripsi Fakultas Ekonomi Universitas Serang Raya.

Hartono, J. (2014). Teori Porto Folio dan Analisis Investasi, Edisi Kedelapan. Yogyakarta : BPFE.

Kritzman, M. P. (1994). What Practitioners Need to Know About Event Studies.

Financial Analysts Journal, 50: 1720.

Megawati Cheng, M., dan Jogi Christiawan, Y. J. (2011). Pengaruh Pengungkapan Corporate Social Responsibility terhadap Abnormal Return. Skripsi Fakultas Ekonomi Universitas Kristen Petra Surabaya. 
Rusnanda, E. W., \& Pardi. (2013). Analisa Pengaruh Pengumuman Merger dan Akuisisi terhadap Abnormal Return Saham Bank Umum di Bursa Efek Indonesia. GRADUASI Vol. 29 Edisi Maret 2013

Pahala, I., Jaya, T. E., \& Meilisa, G. O. (2012). Pengaruh Perbedaan Laba Akuntansi dan Laba Fiskal serta ROA terhadap Cumulative Abnormal Return pada Perusahaan Manufaktur yang Terdaftar di Bursa Efek Indonesia pada Tahun 2009. Econo Sains Vol. 10 Nomor 2 Agustus 2012

Sandrayati. (2013). Pengaruh Pengungkapan Tanggung Jawab Sosial Perusahaan dan Tata Kelola Perusahaan terhadap Return Saham. SEMNAS FEKON.

Thrisye, R. Y., \& Simu, N. (2013). Analisis Pengaruh Rasio Keuangan terhadap Return Saham BUMN Sektor Pertambangan Periode 2007-2010. Jurnal Ilmiah Akuntansi dan Bisnis Vol. 8 Nomor 2 Juli 2013

Yin, R. K. (2009). Case Study Research Design and Methods. Fourth Edition. Vol.5. Sage. USA. 